\title{
Detecting Post-Nuclear Crisis in Hanna Jameson's The Last
}

\author{
Renáta ZSÁMBA \\ Eszterházy Károly University (Eger, Hungary) \\ Institute of English and American Studies \\ zsamba.renata@uni-eszterhazy.hu
}

\begin{abstract}
Hanna Jameson's post-apocalyptic detective novel, The Last (2019), addresses contemporary issues that affect us on both a collective and an individual level. The author diagnoses the denial of nuclearism and calls for an awareness of the nuclear age combined with the looming threat of climate change. The novel negotiates alternative strategies for the treatment of crisis brought about by the nuclear attack and borrows many of the thematic and structural elements from twentieth-century nuclear fictions in which the apocalypse is not necessarily regarded in negative terms but as a chance for regeneration. The events of the post-nuclear months in a Swiss hotel are narrated by an American historian whose written account serves several goals. It gives the illusion of delaying crisis, but it also reveals his fears and traumas conjured up by radioactive spectres. There are two different types of narratives at work, the narrative of the crisis and that of the investigation. The narrator-protagonist becomes obsessed with finding the solution to a murder mystery, which in a metaphorical sense is to give a soothing answer to the death of millions. However, this attempt keeps failing, and thus the narrative of the crisis devours all kinds of rational initiatives to resolve chaos. In order to elaborate on the psychological impact of the post-nuclear crisis in subject construction, I do not only examine the character of the amateur detective of the whodunit whose intervention aims to restore order, but I also apply Gabriele Schwab's concepts of post-nuclear subjectivity and nuclear hauntology.
\end{abstract}

Keywords: post-apocalyptic detective novel, post-nuclear crisis, investigation, trauma, post-nuclear subjectivity

\section{Introduction}

On Day Fifty-Two after a global nuclear attack, Jon Keller, the narrator-protagonist of Hanna Jameson's The Last (2019), records the following remarks in his diary, which he keeps calling "Chronicle": 
Everything that had happened before - our past lives - barely mattered. We lived day to day and could no longer remember all the people we hated, the things that upset us, made us angry online [...] vendettas against journalists, news anchors, politicians, celebrities, relatives... all gone. A girl was murdered, but it had happened before. Before didn't exist anymore. The giant slate of the world was clean. Consequences no longer existed. (60; ellipsis in the original)

Jon, who is one of the survivors of a nuclear holocaust and a former political scientist of Stanford University, is grieving his former life, the banal little things of everyday existence and painfully recognizes his limits to make progress, to bring order and justice into the chaotic present. The confrontation with the failure of the coping strategies he has been trying to fully realize in order to survive and to stay sane not only aggravates his situation but foregrounds ontological and epistemological crisis brought about by the nuclear attack. In Narratives of Crisis, Matthew W. Seeger and Timothy L. Sellnow argue that "[d]isasters create significant confusion. Often [...] those experiencing a crisis are unable to make sense of what is happening. This paralysis often compounds the damage [...] normal conditions are radically and rapidly disrupted. The fundamental sense of personal meaning may be lost as a person's life story takes a sudden and unexpected turn" (2016, n. p.). Jon's personal account of the initial post-nuclear months in a Swiss hotel details the stages of crisis that the members of the community go through from the anxiety to daily disturbances, depression, and new coping methods. Jon's journal, however, meets other rhetorical goals. As a self-appointed detective, he is determined to find a solution to a murder mystery that took place exactly the same day as the nuclear attack. His new position as a sleuth lends him the illusion of heroic qualities that compels him to step up in the face of crisis and, in a metaphorical sense, give a soothing answer to the death of millions. Seeger and Sellnow also remark that "a postcrisis narrative consistently tries to answer the question, 'Who is to blame?' Blame and responsibility for a crisis are fundamental issues that communicators must address" (2016, n. p.). Thus, the account of the crisis transforms into a blame narrative where the goal is to determine blame and responsibility following the attack. In a narrow sense, Jon's aim is to find the murderer, but his secret wish is also to explain the causes that have led to the present disaster. As a consequence, the process of investigation points towards and becomes intertwined with contemporary global and political concerns related to nuclear politics grounded on the denial of nuclearism. Similar to other narratives of crisis, Jon's chronicle is supposed to fill in the communication vacuum, "create larger meaning structures that may be rooted in patterns of association such as cause and effect" (Seeger and Sellnow 2016, n. p.), but it is obviously influenced by his social, cultural, and ideological 
standpoints. While Jon keeps deluding himself that his chronicle in the hotel is exempt from emotional details and qualifies as a record of the last days of history, it is obviously a very personal and intimate form of diary that familiarizes the reader with family stories, his daily routine, and, most of all, the regret for the lost chances to be a better husband and a father. While he reveals his traumas, desires, and fears conjured up by radioactive spectres, he refuses to succumb to the apocalyptic appeal, maintains a hopeful tone, and struggles to make progress. This twofold image of the apocalypse has been an often contested issue in nuclear holocaust fictions. The image of the "giant slate of the world" being clean marks the ambivalence inherent in apocalyptic imaginary. On the one hand, it conjures up the horrors of complete destruction, but, on the other hand, it also signals a new beginning, which gives apocalyptic stories a new horizon.

In Writing the Apocalypse, Lois Parkinson Zamora remarks that apocalyptic visions have inspired a significant body of imaginative literature and visual art since the Middle Ages $(1989,1)$, but the past two decades have seen an increase in the negotiation of such visions in the light of crisis in global terms: "The word is used again and again to refer to the events of recent history, whether nuclear or ecological or demographic, which suggest all too clearly our ample capacities for self-destruction” (Zamora 1989, 1). Gabriele Schwab’s Radioactive Ghosts joins this argument by pointing out that "[t]he nuclear age, and especially the memory of Hiroshima and Nagasaki, the Cold War, and the antinuclear resistance movements, as well as the nuclear disasters like Chernobyl ${ }^{1}$ and Fukushima continue profoundly to mark the cultural imaginary and nourish fantasies" (2020, n. p.). Experimental texts reveal the deepest anxieties about the past and the future of the planet as well as that of the human species, which create a double haunting. The knowledge of the past and its possible return in the future terrifies us, so as a form of defence mechanism we remain blind to the damage and perennial risks nuclear bombs have done in the world as well as to the consequences that the spectral presence of radioactive contamination might have in the future. Thus, images of remainderless destruction brought about by nuclear war have always challenged the "trope of unrepresentability" (Schwab 2020, n. p.), which creates a pervasive paradox in apocalyptic imaginary. Schwab quotes Jacques Derrida's essay "No Apocalypse, Not Now" to explain the deeply ambivalent feature residing in the tension between the two modalities of visualizing total annihilation. According to Derrida, what lies at the core of this ambivalence is the inability to disregard the "destructive potential of nuclear weapons" on the one hand and to give in "to the lures of the apocalyptic

1 For example, a recent Hollywood movie, Upside Down (2012), reproduces the ghastly images of the Chernobyl catastrophe. In his article, Norbert Gyuris claims that the spatial imagery of the apocalypse in the movie heavily feeds on the dark and empty streets of Pripyat, its abandoned and ruined buildings in a heavily polluted environment (2015, n. p.). 
imaginary" (qtd. in Schwab 2020, n. p.) on the other. The following quote justifies this claim: "This ambivalence creates an inescapable double bind: the refusal to imagine extinction would amount to buying in to the politics of denial, and (self-) deception; succumbing to the apocalyptic imaginary, on the other hand, would amount to buying in to the ecology of fear and annihilation that enables nuclear necropolitics in the first place" (Schwab 2020, n. p.). This paradox then urges literature to produce "concord fictions" to find "ever-new modes of indirection by inventing strategies of speaking of other things for putting off the encounter with the wholly other $[. .$.$] The question of indirection as a response to the limitations$ [...] of quasi-realistic representations profoundly shapes debates about nuclear fiction" (qtd. in Schwab 2020, n. p.).

Hanna Jameson's book, a post-apocalyptic detective novel, is one of the latest attempts to grasp the anxiety and the apocalyptic vision that surround the nuclear age, yet it escapes the direct treatment of remainderless destruction. While The Last explicitly addresses the fears of an anticipated nuclear attack and its possible aftermath, it satisfies itself with the "quasi-realistic" representation of a nuclear holocaust and wards off the fears of total annihilation in favour of a utopian or even a nostalgic vision of returning to a primitive, pre-historic condition. Jameson seeks to soften reality and soothe the traumas of death with various methods. Among these, there is the vision of survival that Schwab also describes in her book: "However, ever since humans began to imagine extinction in apocalyptic visions and stories, they have also supplemented them with stories of precarious survival" (2020, n. p.). Jon's moral message at the end of the book, "[i]nstead of a conclusion, we've been offered nothing but more life" (Jameson 2019, 390), ties in religious undertones. Despite the temporary loss of faith, the narrator is not only the last one in the community to know and quote the Scripture, but he often thinks about fate or God's providence that has brought him to Switzerland and saved him from death. From this perspective, the initial dystopian vision embodies a utopian one that connects the narrative to the biblical apocalypse in which the apocalypse "is not merely a vision of doom [but] [...] a luminous vision of the fulfilment of God's promise of justice and communal salvation" (Zamora 1989, 2). According to Elena Gomel, "the horror of macroscale destruction" $(1995,345)$ is, however, a pre-condition to rebirth that allows for "the establishment of the New Jerusalem" $(1995,345)$. It is, however, only in isolated communities where the "promise of micro-scale regeneration and renewal" $(1995,345)$ can be realized. In the novel, the destruction of the nuclear bombs is distanced from the survivors located in a remote hotel somewhere in a forest. This way environmental contamination and the various responses to the crisis can be more highlighted without the absolute confrontation with extinction and the dread of killing. Although Schwab scornfully remarks that "[t]he apocalyptic imaginary can all too easily be co-opted for all kinds of 
purposes" (2020, n. p.), which is a reference to the distorted representations of Hollywood productions, Jameson's novel proves to be a serious book in raising awareness of the nuclear perils and advocating "political urgency of imagining extinction" (2020, n. p.). Nevertheless, the fact that the author forecloses mourning with the utopian vision of a new world in the end might undermine such ambitions. The major concern of portraying the end of the world, however, does not lie so much in this particular controversy than in the intersection of two types of narratives, that is, the narrative of crisis and the narrative of detection. This way, The Last joins the latest trend of exhibiting “crime fiction's ability to depict and discuss ecological crises and abuses [as well as to] directly expos[e] the criminal acts they involve and their violent effects on people and the environment" (PuxanOliva 2020, 362). The fact that the nuclear attack and radioactive contamination are also forms of ecocrime demonstrates the ability of various subgenres of crime fiction to constantly renew themselves and divert the attention from local to global levels. ${ }^{2}$ The combination of diverse genres obviously results a hybridized form and demonstrates the experiments that authors of mystery novels have been making to renegotiate the conventions of the genre. The fact that Jameson has thrown the conventional patterns of the whodunit against the narrative of postapocalyptic crisis is a brilliant way to challenge the genre's limits and revise the concept of crime and criminality. Furthermore, finding a solution to a murder mystery proves to be an alternative method for Jon Keller to delay the psychic impact of the unexpected disaster. This establishes a parallel between him and the deeply traumatized gentleman sleuth of the classical formula in which the detective's compulsion to investigate is an escape from his wartime traumas. Just like Golden Age detectives who attempt to treat the chaos of modernity and end the confusion with rational means after WWI, Jon's loss of ontological and epistemological security due to the nuclear attack also calls for "some immediate action to alleviate the potential threat" (Seeger and Sellnow 2016, n. p.). Susan Rowland argues that "[t]he golden age novel presents a self-referential social scene as a metonym for the wasteland of modernity. The detective quests for the grail, which is the healing knowledge of the source of social sickness [...] Once this knowledge is possessed, the criminal can be removed and thereby the wasteland renewed" $(2010,122)$, and thus the ultimate desire to solve death and

2 Puxan-Oliva also remarks that the capacity of crime fiction to reflect on global problems and the future of the human species allows for considering the genre within the field of world literature. In The Global Novel: Writing the World in the $21^{\text {st }}$ century, Adam Kirsch attempts to come up with a definition of the global novel despite the fact that critics consider it a disputable category: "The novel is implicitly global as soon as it starts to speculate on or record the experience of human beings in the $21^{\text {st }}$ century. Global novels are those that make this dimension explicit [...] The global novel exists, not as a genre separated from and opposed to other kinds of fiction, but as a perspective that governs the interpretation of experience [...] The local gains dignity, and significance, insofar as it can be seen as part of a worldwide phenomenon” (2016, n. p.). 
evil is fulfilled. Nevertheless, the quest for truth and solution is not that simple, the detectives usually face danger, confusion, or social unfairness that reinforces "the impermeability of modernity to reason" $(2010,122)$. Although Golden Age detectives never fail in resolving the puzzle, they are rarely immune to the crime they are involved in. Their very presence is a sign of moral transgression which they seek to hide with control and moral superiority justified by their uppermiddle-class or aristocratic status. Despite many of the similarities, Jameson's narrator does not share the intellectual success of the gentlemen detectives. His endeavour in meaning making or finding truth fails, and his investigation creates a vicious circle driving him back to the start to be ceaselessly confronted with his traumas and the inability to make progress. This suggests that the two types of narratives do not only run parallel with but also against each other. It is the aim of the present paper to examine how the narrative of detection and that of the post-nuclear crisis complement and refute each other in order to explore contemporary discourses of the nuclear imaginary.

\section{Mysteries of Crisis and Investigation}

In the opening scene of the novel, Jon Keller is waiting for his conference talk in L'Hotel Sixième, near Zurich, "in the middle of nowhere" (Jameson 2019, 3). He recalls his wife telling him about the darkest nightmare she had one night: "Nadia once told me that she was kept awake at night by the idea that she would read about the end of the world on a phone notification [...] For me, three days ago, it happened over a complimentary breakfast" (Jameson 2019, 3). Although Jon admits that he has not been alert since their conversation, he could not erase Nadia's words from his mind. He feels stupid and unprepared, although in retrospect he admits that there were warning signs of the crisis which he either did not take seriously or deliberately ignored. His refusal or blindness to the nuclear peril are exactly the symptoms of how nuclear subjectivities, or, in other words, our experience of and relation to nuclearism, have been shaped since the Second World War according to Gabriele Schwab, whose main interest lies primarily in the impact of the nuclear age on psychic life. She claims that "[i]n relation to nuclear threat, familiar psychic defence mechanisms, such as splitting, doubling, dissociation, denial, moral inversion, deceit, psychic encryption, forgetting, and, in some cases, even traumatic amnesia, have become common conditions of human functioning in everyday life" (2020, n. p.). While reflecting on fragments of his former life, Jon remembers escorting his wife to protest marches back at home in California, which, however, did not seem serious for him at all: "I remembered feeling doom-laden about politics, but there had been no sense of urgency in me [...] Even after all the marches I accompanied Nadia to, all the 
antinuclear protests that had made me feel like I was living in the sixties, the mounting hysteria, I had never believed it" (Jameson 2019, 121). It is only after the attack has happened that Jon realizes his useless liberalism and his failure to take political action. Schwab also argues that denial is a form of self-defence but it carries real dangers:

Many do not want to think or even know about the full extent of the nuclear threat [.... This means that we go on living as if the nuclear danger were not there [...] But as a coping mechanism, splitting also creates a scarring psychic rift that is potentially threatening, not only because it causes the ontological insecurity of divided selves, but also because it reduces the felt urgency for political action and resistance. (2020, n. p.)

Denial and psychic splitting that generate the nuclear unconscious stand in the core of her theory of nuclear subjectivities, which Jameson also diagnoses in her novel. Jon's intentional blindness to "the damage done by innumerable atomic tests in the United States and around the world" (Schwab 2020, n. p.) is symptomatic of the defence mechanisms against fear. Jon's bitter remarks about his unthinking attitude towards the ongoing threats are echoed in his diary a few weeks later, when he feels capable of recalling Day One, the day of the bombings: "My hands started shaking. I couldn't read. All I could see was the word NUCLEAR. I caught myself. It couldn't be actually nuclear. Not in that way. Nuclear meant the end" (Jameson 2019, 63). Jon is not only exposed to confronting with his ignorance towards the threats of nuclear war, but his urge to place accusations on a particular group is doomed to failure despite the fact that someone has actually initiated a nuclear attack. His notes “I heard, 'They’ve bombed Washington!', and even now I'm unclear on who they were" (Jameson 2019, 68; emphasis in the original) might also imply that there will be no monstrous other to put the blame on. Another hint at his indifference to political urgency is described at the end of his "chronicle". He tells us about the night before he left for the conference. His wife Nadia was watching a demonstration against nuclear arms on TV. In retrospect, Jon feels that he has not only disregarded the signals of a nuclear attack but he has always been a man to avoid confrontation and resolve problems in his marriage too: "The banners being shown on TV were all the same: STOP DOOMSDAY. END THE NUCLEAR RACE. That kind of thing. I had poured myself a glass of wine while bitching about one of Marion's teachers" (Jameson 2019, 376). Schwab points out that "[t]hose [...] who are exposed to the media but brush their fears aside [...] are all the more affected by the nuclear unconscious" (2020, n. p.).

On the first day of the attack, Jon's seeing the images of the nuclear attack hitting various cities in the USA and different parts of Europe generates diverse emotional responses ranging from total devastation to disbelief and even relief. First he feels 
that his eyesight and hearing stop functioning properly, and then everything goes blank. Nevertheless, two months later when he recollects the events of the first day and comments on the sight of "[the] blinding flash of light, the cloud - the biggest cloud [he] had ever seen" (Jameson 2019, 64), he demonstrates a rather different attitude which proves that he has started to process and interpret the moment when history ended. Jon explains that his refusal to believe what he saw is rooted in the various Hollywood productions about a possible apocalypse which reminds us of Schwab's claim about apocalyptic texts and films: "the apocalyptic imaginary in general inevitably entail[s] a symbolic domestication of the ultimate threat of nuclear destruction” (2020, n. p.). Jon's self-reflexive comments justify Schwab's point about the domestication of nuclear violence: "It didn't seem as real as the headlines. Maybe we had all been desensitized to the imagery by too many movies" (Jameson 2019, 5). Following the dropping of the atomic bombs, the group in the hotel has no longer access to news or Internet connection. On the first day, Jon notes: “Now we can't send emails" (Jameson 2019, 4) and a couple of weeks later: "Then, it became hard to get news from anywhere but social media, because most of the TV channels were no longer broadcasting” (Jameson 2019, 68). According to Seeger and Sellnow, crises in general "precipitate a meaning deficit by disrupting [...] the patterns of sense making. During a crisis, communication channels [...] are often cut off. [...] There is a need, therefore, to tell stories and offer accounts and explanations to reduce the uncertainty [...] and create or recreate meaning" (2016, n. p.). Experiencing total isolation and a meaningless existence, Jon's first response to coping with crisis is to start recording the events of the days. Writing becomes a therapy, a new goal to get up for, a means to interpreting the abnormal situation and remain sane: "I'm going to keep writing. I feel like if I don't keep writing, I'll lay down and die" (Jameson 2019, 18). Jon's quick decision to start writing is not only among the limited available resources he has access to, but it is also part of the psychological need to return to "precrisis function and a sense of balance or homeostasis" (Black and Flynn 2020,32) that individuals in crisis seek with the goal of restoring their former condition. In this sense, the act of writing also offers the possibility to revise and re-interpret one's past, to reflect on change, and also to create a sense of unity in the midst of chaos. Since Jon's diary also qualifies as a sort of autobiography that tells fragments and memories of his life, it is also the moment where his narrative identity, ${ }^{3}$ a theory formed by Paul

3 The concept of narrative identity was developed by Paul Ricoeur, who claimed that the self comes into being and to an understanding of "one's self in the world" (Crowley 2003, 3) through the act of telling a life story. According to his theory, identity is divided into two categories: idem and ipse. "Idem refers to a notion of identity based on Sameness[,] whereas ipse, described as Selfhood, can incorporate change within a recognizable entity. In Time and Narrative, ipse is analogous to narrative identity and involves the telling and reading of a life-story, whether factual or fictional, such that the figure of identity that emerges offers a new insight into the self" (Crowley 2003, 1-2). 
Ricoeur, evolves. One example of narrative identity that Ricoeur suggests in his Time and Narrative "is based on Freud's clinical work with individuals whose cure involves making narrative sense of the fragments of memory and stories that disorder their sense of identity" (Crowley 2003, 3). Ricoeur also remarks that "the subject comes to self-knowledge through the construction of a 'coherent and acceptable story' about himself” (Crowley 2003, 3). The diary becomes a form of a talk cure where Jon becomes both the writer and the reader of his own story that help him locate himself in a post-apocalyptic world. Apart from detailing the impact of the catastrophe on an individual and collective level, the diary also becomes crucial in maintaining a dialogue between the reader and the writer, which is one of the most important elements in classical detective fiction when it comes to investigative methods and procedures.

On Day 50, Jon and two members of the hotel staff find the dead body of a nineyear-old girl in one of the water tanks on the roof of the hotel while they are trying to inspect the cause of the bad taste of the tap water. Finding the unidentified corpse of the little girl establishes the mystery element and triggers the detective's work. Classical whodunits that stem from Edgar Allan Poe and Arthur Conan Doyle started to flourish in the interwar era and are notorious for their formulaic structure. Although the Golden Age of detective fiction is extremely diverse, there is an organizing element that most authors submit themselves to: "The works of the Golden Age authors often project worlds of radical rationality, in which the chaos and senselessness associated with crime are vanquished by the investigator's transcendent reason" (Shiloh 2011, 12). The pursuit of crime requires logic, the collection of evidence, and deductive skills, all of which drive the detective to the resolution. While Golden Age sleuths intend to maintain a rather cold, rational, and objective image during their investigation to highlight the triumph of reason, they cannot remain detached from their social and cultural context; in reality, they become symptomatic of war traumas. Their intervention has several goals. They are to map out the chaos of modernity in search of truth, knowledge, and reality, soothe post-war traumas, and seek to find rational means to explain the death of millions in the First World War. Gill Plain comments on this feature in interwar detective fiction: "Someone is to blame, and the wartime absence of explanation is superseded by detective fiction's excess of possible solutions" $(2001,34)$. In interwar whodunits, detection is often a form of selftherapy to heal war traumas, just like in the character of Dorothy L. Sayers's Lord Peter Wimsey. Wimsey's hobby to investigate grows out of the desire to suppress his shell shock, yet the sight of the dead corpses and engagement in criminal deeds lead him "inexorably back into the reworking of the very depression he seeks to assuage” (Plain 2001, 48). Jon's desire to give himself a detective project suggests an explicit parallel between him and classical gentleman detectives. He is traumatized by losing his family and having to cope with the aftermath of a 
nuclear attack. He investigates to find meaning, keep control, and, at the same time, avoid confrontation with reality, but the investigation itself forces him to relive what he is escaping from; his psychological inadequacy and the sight of the dead body ceaselessly signal chaos. Representing authority as a white uppermiddle-class male, he contends that the categories of right and wrong still exist and that by finding the murderer he could eliminate evil and find truth. Seeger and Sellnow point out that "[c]risis narratives pit the protagonist against the antagonist in a struggle to restore order from the chaos of crisis" (2016, n. p.). Given that a post-crisis situation entails uncertainty and confusion, leadership is wanted "for the kind of direction and coherence" that it can provide (Seeger and Sellnow 2016, n. p.). Jon's taking charge of the investigation borrows him a new position in the community, as Seeger and Sellnow remark, "[b]y imposing order on chaos $[\ldots]$ the leader may become a hero" (2016, n. p.). In this sense, Jon has a reason to "thank the Bomb" (Gomel 1995, 344) since he can prove his masculine virtues, leadership skills, and intellectual superiority. Gomel claims that the nuclear holocaust is a "blessing in disguise [for] the protagonist" (1995, 344) since he can become an independent man, "the leader of the community" (1995, 344). Although detectives are supposed to exude the image of heroism, it is rarely the case in Golden Age detectives who demonstrate reduced masculinity and are relatively anti-heroic. While Jon undoubtedly becomes one of the leaders in the community, he relies on masculine strength and aggression only in extremis. Instead, he often gets too emotional and irrational being so much involved in the murder case. The dead corpse of the young girl keeps reminding him of his daughters whom he feels he has let down. Capturing the murderer becomes a mission, which also nourishes the illusion that he is capable of protecting others, especially his family he has probably lost for good. He often fights with his rational and irrational sides, and investigation is the only strategy to retain control. While searching the room of the family whose daughter has probably been murdered, he is overwhelmed by fear and despair: "I sat on the Luffmans' bed and thought I was going to cry, but I managed to keep it together. It had been a while - too long - and the urge to lose control scared me, I didn't know what else I might end up doing if I gave in to it” (Jameson 2019, 55).

Jon's methods for investigation follow the same course of those of the amateur detectives of the classical formula, yet he cannot reach the solution. There is no evidence to be collected, no clues to be read, no witnesses left. He even fails to make sure about the identity of the dead girl. He unwillingly admits that the struggles to survive have overridden all other concerns, so his strategy to treat crisis with rationality and control seem to be failing: "Survival takes up so much space. The rest of the time, when I'm not surviving or writing, I deliberately occupy my mind with other tasks, like trying to find out more about the girl in the water tank [...] That being said, I still feel like I'm letting down Harriet 
Luffman. I haven’t got any closer to finding her killer” (Jameson 2019, 255). Another reason for his failure is the resistance of the survivors in the hotel to co-operate with him. They are either uninterested, have lost faith in everything, or resent Jon's enthusiasm to stand for authority. A conversation with Sophia, the cook of the hotel, clearly indicates that Jon has been totally left alone in his mission: "You know what we think of as right and wrong don't exist anymore. [...] No one is coming to enforce law. Even if you did find her killer, which you won't, no one is coming to take him away. What will you do? Do you think you're the law now?" (Jameson 2019, 167). Jon is so much blinded by his good will to solve the puzzle that he tends to forget about his own involvement in violence. It is exactly his participation in carrying out a violent act on others, such as his approval of the execution of one of the survivors in the hotel, that not only blurs the categories of right and wrong but also proves that the detective and the criminal are secret sharers.

Given the fact that the detective is rid of his potential to make meaning "in an era of wide-scale environmental crisis, [his] reassuring and restorative functions must, once again, be reconsidered" (Walton and Walton 2018, 2). Critics who apply ecocriticism to crime fiction argue that some deviations from the classical formula that the detective exhibits in environmental crime fiction, such as "the execut[ion] of justice extrajudicially, or present[ing] solutions that are wrong, partial or come too late to change the course of events [...] grow in significance and centrality in the figure of the ecological detective" (Walton and Walton 2018, $3)$. In cases of an "escalating climate catastrophe [...] ecological detectives may be called upon to bear witness, diagnose, organise, protest, persuade, suffer, mourn, and act" (Walton and Walton 2018, 3). Jon Keller's role as a detective becomes more promising when it comes to witnessing and diagnosing the impact of the nuclear catastrophe on both nature and the community. During the first few weeks, Jon examines the trees, the weather, and the clouds to inspect the changes in the natural habitat. He reports on the insects being silent, the birds disappearing, the trees browning and dying, the lack of sunshine, and the cold weather despite the summer season. He understands that nuclear catastrophes enact long-term radiation and slow death, but he is fairly unsure how radiation exactly works and how it impacts his body. His uncertainty about the effects of radiation refers to the uncanny effect produced by radioactive contamination. Joseph Masco's The Nuclear Borderlands explains that "nuclear materials are sources of invisible power. Radiation is colorless and odourless, yet capable of affecting living beings at the genetic level. In this sense, nuclear materials produce the uncanny effect of blurring the distinction between animate and inanimate [...]" (qtd. in Schwab 2020 , n. p.). The majority of Jon's diary, however, is not so much dedicated to the environmental changes than to the coping strategies of the survivors in the hotel. Apart from the immediate response to the crisis culminating in a couple 
of suicides, ${ }^{4}$ Jon also reflects on how the nuclear attack shapes the psychic life of the survivors and contours the emergence of post-nuclear subjectivities. Schwab uses the term "in reference to the subjectivity of survivors of nuclear attacks of disasters" (2020, n. p.), namely those of Hiroshima, Nagasaki, Chernobyl, and Fukushima. Analysing the testimonies of survivors, she gets to the conclusion that they can be read "as paradigmatic of postnuclear subjectivities" $(2020, \mathrm{n}$. p.). Common features marking post-nuclear subject formations generally include "obsession with illness developing in radioactively contaminated bodies; fears of reproductive damage and related phantasms of the mutant body; the phantasmatic refashioning of the disaster zone into an idyllic space of freedom; haunting from the future linked to the vision of planetary extinction" $(2020, \mathrm{n}$. p.). In the novel, the reader witnesses almost all of these features discernible in the psychic disposition of the characters. The fear from illnesses and the lack of enough medicine is one of the most emphasized concerns. When they seem to be running low on available medicines and pills, a little group of people go into the city armed with guns to get some. For Jon, this is the first time to confront with anarchy, given that two of his former colleagues from the university need to be shot in order to take possession of the drugs. Other visions also haunt the characters, including the future of the human species, reproduction, and the fate of new-born babies. Paralysed by the fear of death, some men show signs of atavism in their sexual impulses. One of the residents tries to rape a young girl and accuses the others of taking possession of all the available women in the community. Although his sentence is death penalty for the attempt, the other men keep fantasizing about possible ways to save the planet. Jon is witnessing a conversation between two of his friends and concludes that the gender divide has not only deepened, but the male compulsion to maintain life would reduce women to self-replicating machines: "I was mortified at the thought that any of the women here might find out about this; three men in a room discussing their reproductive rights like they weren't even people now that civilization had gone" (Jameson 2019, 160).

All these anxieties become resolved when the community finally decides to leave the hotel in fear of being hunted by violent gangs hiding in the forest. Upon arriving in the city of Saint-Sion, Jon's first remarks in his diary delineate a utopian community: "Long live Saint-Sion! PEACE. It's a city, but not like any I remember. It's like a myth I heard once, about a word like 'community', but I never saw it realized in any part of the society we'd built before" (Jameson 2019, 372). Jon's reaction to order and peace implies the restoration of religious beliefs

4 Grounding on Juliet Mitchell's theory of trauma, Judit Kusper claims that trauma can violate one's defence mechanisms with such great intensity that the subject can no longer cope with the aftermath regardless of the event being foreseen or not. Suicide is a response to an unexpected crisis where the subject is left with no available coping strategies to heal the trauma $(2020,440)$. 
he has lost; the idyllic picture of the houses, children, and people promises a return to an Edenic state. This hopeful vision about the future after a nuclear catastrophe echoes Schwab's description of how Chernobyl survivors related to the zone of exclusion: "Nuclear haunting from the future provokes a highly ambivalent oscillation between apocalyptic fears and their counterpart, [...] a creation of postnuclear Eden [...] the fantasies of a postnuclear idyll are survival fantasies, designed to ward off the fear of the devastating short- and long-term effects of the fear of repetition" (2020, n. p.). While this type of attitude reinforces powerful denial according to Schwab, it enables the survivors to put up with the threatening and precarious conditions. In Jameson's book, the dread of the future is replaced with the idea of a utopian community where money has no use, where new ways of farming are being devised, where the levels of radiation in the water are still very low. Gomel's observation of survival fantasies draws on similar conclusions: "In fact, those characters who do not commit suicide or otherwise perish after the Day are much better off at the end of the novel than at its beginning. A collection of vaguely dissatisfied loners, they eventually band together to form a utopian community" $(1995,344)$. This peaceful sight is only shattered by the presence of armed soldiers who maintain peace with guns to enforce law and order. Maintaining peace and freedom with violence has been a contested issue not only in crime and apocalyptic fictions but also in political, cultural, and historical discussions that explore nuclear threats (Schwab 2020, n. p.). This contradiction, however, creates a heterotopia given that two types of worlds, a utopian and a dystopian, are juxtaposed in Saint-Sion as if reminding the residents of the illusory consolation that utopias can offer: "although they have no real locality there is nevertheless a fantastic, untroubled region in which they are able to unfold; they open up cities with vast avenues, superbly planted gardens, countries where life is easy, even though the road to them is chimerical" (Foucault 1994, n. p.). The initial optimism about moving into the city and upon the sight of a harmonious life is slowly undermined by violence, which is a hint at the omnipresence of crime. Jon's personal mission has almost terminated, with one exception. While the investigation has failed him, he cannot escape meeting the culprit and facing another trial. Although he envisions a brighter future, his passive observation of the murderer beaten to death casts a shadow on a new start. Jon's detective work to find someone to blame has failed, and even if the murderer has been eliminated in the end, he cannot cope with the larger scale of crime: nuclear violence and environmental crime. 


\section{Conclusion}

Jon Keller's goal to write a chronicle, regain control, and find truth to reorder chaos prove to be aborted ambitions in a post-nuclear world. Although he has recognized collective responsibility for the disaster, he keeps displacing his anxiety into the detective project and find an individual to blame. His bitter words about his own ignorance and the denial of nuclear threats clearly indicate that all humans are participants in nuclear violence. In the end, the only option left is to restore the image of humanity with the hope of a new beginning in a utopian world to escape the sight of the ruins they have caused. Similar to the traumatized sleuths of the Golden Age, who evade reality by recapturing unity with the mythical English landscape, Jon is also ready to bury his traumas in the mythical community of Saint-Sion.

\section{Works Cited}

Black, Linda Lutisha and Stephen V. Flynn. 2020. "History and Theoretical Foundations of Crisis and Crisis Counseling". In Crisis, Trauma and Disaster, 27-72. Los Angeles: SAGE publications.

Crowley, Patrick. 2003. "Paul Ricoeur: The Concept of Narrative Identity, the Trace of Autobiography”. Paragraph vol. 26, no. 3(Nov.): 1-12. https://www.jstor.org/stable/43263868 (Last accessed 2 June 2021).

Foucault, Michel. 1994. The Order of Things. An Archaeology of the Human Sciences. E-book, Vintage Books Edition.

Gomel, Elena. 1995. "Mystery, Apocalypse and Utopia: The Case of the Ontological Detective Story”. Science Fiction Studies vol. 22, no. 3(Nov.): 343-356. https://www.jstor.org/stable/4240456 (Last accessed 15 September 2021).

Gyuris, Norbert. 2015. "Fejtetőre állított világok: binaritás és egység az Upside Downban" [Toppled Worlds: Binaries and Unity in Upside Down]. Apertúra, Tavasz-Nyár.

https://www.apertura.hu/2015/tavasz-nyar/gyuris-fejtetore-allitott-vilagokbinaritas-es-egyseg-az-upside-downban/ (Last accessed 2 April 2021).

Jameson, Hanna. 2019. The Last. London: Penguin Books.

Kirsch, Adam. 2016. The Global Novel. Writing the World in the $21^{\text {st }}$ Century. Kindle ed., New York: Columbia Global Reports.

Kusper, Judit. 2020. “Az otthonosság szomorúsága. A szimbolikus és retorikai otthonosság Gárdonyi Géza $A z$ öreg tekintetes címú regényében” [Sad Domesticity: Symbolic and Rhetoric Homeliness in Géza Gárdonyi's The Old Respectable]. Irodalomtörténet vol. 51, no. 4: 421-441. 
http://epa.oszk.hu/02500/02518/00370/pdf/EPA02518_irodalomtortenet _2020_04_421-441.pdf (Last accessed 25 March 2021).

Plain, Gill. 2001. Twentieth-Century Crime Fiction. Gender, Sexuality and the Body. Edinburgh: Edinburgh University Press.

Puxan-Oliva, Marta. 2020. "Crime Fiction and the Environment." In A Routledge Companion to Crime Fiction, eds. Janice Allan, Jesper Gulddal, Stewart King and Andrew Pepper, 362-370. London: Routledge.

Rowland, Susan. 2010. "The 'Classical' Model of the Golden Age." In $A$ Companion to Crime Fiction, eds. Charles J. Rzepka and Lee Horsely, 117-127. Oxford: Wiley-Blackwell.

Schwab, Gabriele. 2020. Radioactive Ghosts. Kindle ed., Minneapolis: University of Minnesota Press.

Seeger, Matthew W. and Timothy L. Sellnow. 2016. Narratives of Crisis. Telling Stories of Ruin and Renewal. Kindle ed., Stanford: Stanford University Press.

Shiloh, Ilana. 2011. The Double, the Labyrinth and the Locked Room. Metaphors of Paradox in Crime Fiction and Film. New York: Peter Lang.

Walton, Lindsay Jo and Samantha Walton. 2018. "Introduction to Green Letters. Crime Fiction and Ecology”. Green Letters vol. 22, no. 1: 2-6. https://doi.org/10.1080/14688417.2018.1484628 (Last accessed 26 February 2021).

Zamora, Lois Parkinson. 1989. "Introduction: The Apocalyptic Vision and Fictions of Historical Desire”. In Writing the Apocalypse. Historical Vision in Contemporary U.S. and Latin American Fiction, 1-24. Cambridge: Cambridge University Press. 